\title{
CADMIUM CONCENTRATIONS IN SOTALIA GUIANENSIS (VAN BÉNÉDEN, 1864) IN A TROPICAL ESTUARY, SOUTHEAST OF BRAZIL.
}

\author{
SALGADO, L. D. ${ }^{1,2}{ }^{*}$; CARVALHO-NETO, F. S. ${ }^{3}$ \& FILLA, G. F. ${ }^{1,4}$ \\ 1- Instituto de Pesquisas Cananéia, Cananéia, São Paulo, Brazil. \\ 2- Programa de Pós Graduação em Ecologia e Conservação, Universidade Federal do Paraná, \\ Curitiba, Paraná, Brazil. \\ 3- Universidade Positivo, Curitiba, Paraná, Brazil. \\ 4- Instituto Federal do Paraná, Campus Curitiba, Curitiba, Paraná, Brazil. \\ *Corresponding author: Iilian.salgado@hotmail.com
}

\begin{abstract}
Salgado, L. D.; Carvalho-Neto, F. S.; Filla, G. F. 2014. Cadmium concentrations in Sotalia guianensis (Van Bénéden, 1864) . Braz. J. Aquat. Sci. Technol. 19(1):39-45. elSSN 1983-9057. DOI: 10.14210/bjast.v19n1.p39-45 Cadmium concentrations were assessed in the hepatic tissues of 27 Guiana dolphins, Sotalia guianensis, that were found stranded in the estuary of Cananéia-Iguape, southeast of Brazil, between 2009 and 2012. The samples' digestion was performed through acid digestion with $\mathrm{HNO}_{3}$ and the quantification was held by flame atomic absorption spectrometry (FAAS). For 11 of the sampled animals, concentrations did not exceed the limit of quantification of $0.1 \mu \mathrm{g} \cdot \mathrm{g}^{-1} \mathrm{stipulated} \mathrm{by} \mathrm{the} \mathrm{method.} \mathrm{The}$ concentrations varied from above detection limit to $1.79 \mu \mathrm{g} \cdot \mathrm{g}^{-1}$ (wet weight), for a average of $0.39 \mu \mathrm{g} \cdot \mathrm{g}^{-1}$ which is in accord with the literature, as low values of the metal were commonly found in the tissues of the specie on the Brazilian coast. No differences were observed in the accumulation of cadmium between sexes, age classes or the curvilinear length. The accumulation found in the livers may reflect the Guiana dolphins diet in the region and the bioavailability of the metal in the system. This study provides new data about the accumulation of cadmium in animals of the Brazilian coast, contributing towards the status of conservation of the specie.
\end{abstract}

Key words: pollution, metals, estuary, marine mammals, cetaceans

INTRODUCTION

The Guiana dolphin (Sotalia guianensis) displays a coastal habit from its distribution that extends from the Santa Catarina State, south of Brazil, to Honduras, Central America (Flores \& Da Silva, 2009). These animals show a preference for estuarine environments, where there is large supply of food, shelter and refuge from predators (Da Silva \& Best, 1996). Researches show that the species exhibits a residence pattern of greater use in certain areas of Brazil, as for example the Cananéia estuarine region (Santos et al., 2001; Santos \& Rosso, 2008), where they are present the whole year, with a population of about 200 animals (Havukainen et al., 2011).

The Complexo Estuarino Lagunar de CananéiaIguape is classified as one of the most productive estuaries in the world and one of the most preserved ecosystems of the Brazilian coast (Schaeffer-Novelli et al., 1990). It shelters many environmental conservation areas and does not present an expressive anthropic activity, nevertheless, the estuary suffers from metal contamination resulting from mining activities of lead in the basin of the Ribeira de Iguape river (Mahiques et al., 2009). According to Cardoso \& Chasin (2001) the contamination associated of cadmium can happen together with the mining of $\mathrm{Pb}$.

As long-lived animals and occupying high trophic levels, dolphins have great potential for accumulating high contents of heavy metals in their tissues (Siciliano et al., 2005; Bossart, 2006). Higher contents of cadmium have been reported in renal tissue in marine mammals due to its visceral distribution pattern, nevertheless, the liver has a great potential for accumulating different heavy metals, actively participating in the stocking and in the metabolism of toxins (O'Shea, 1999; Kunito et al., 2004). Additionally, the metallothioneins may act in the detoxification of $\mathrm{Cd}$ in the organism as it has the capacity to retain the metal and can reduce its toxicity (Das et al., 2000). Since hepatic and renal cells are the largest producers of those proteins, the accumulation of the metal occurs preferentially in those tissues (Kägi, 1991).

Due to the lack of studies, S. guianensis has its conservation status defined as "Insufficient Data" by the International Union for Conservation of Nature (IUCN) (2014). More researches are necessary, mainly to diagnose the impacts caused by habitat pollution (Monteiro-Filho et al., 2006). In view of these characteristics, efforts are being made by scientific researchers of the region to amplify studies and guarantee a preservation area for the Guiana dolphins (Filla et al., 2008). Collaborating with that, the purpose of this study is to investigate the contents of cadmium in the liver of the Guiana dolphin population in the region and compare them to literature, providing new data about the accumulation of metals in cetaceans of the Brazilian coast, contributing towards the formation of an updated picture of the conservation status of these animals. 


\section{MATERIALS AND METHODS}

\section{Study area}

The Complexo Estuarino Lagunar de CananéiaIguape (Figure 1) corresponds to a complex system, among four big islands (Cardoso, Cananéia, Comprida and Iguape), with long and narrow channels that extend nearly parallels to the coast. It is situated in the extreme south of the São Paulo State, southeast Brazil, between the latitudes $24^{\circ} 50^{\circ}$ to $25^{\circ} 10^{\prime} \mathrm{S}$ and longitudes $47^{\circ} 25^{\prime}$ to $48^{\circ} 00^{\prime} \mathrm{W}$, with a total area of $2.500 \mathrm{~km}^{2}$ (Tessler \& Souza, 1998).
The contribution of fresh water to the system comes from two basins. The first is formed by the Ribeira de Iguape River and its tributaries which drain the whole south of the State (a region known as the Vale do Ribeira). This river entered the system through an opening of an artificial channel called Valo Grande, in 1848, causing various alterations, among them, the salinity, sedimentation and aport of metals. The second basin is close to the Cananéia Island and is constituted by the rivers: Taquari, Mandira, das Minas, Itapitangui and various small rivers that cover close to $1.339 \mathrm{~km}^{2}$ (Bonetti-Filho \& Miranda, 1997; Mahiques et al., 2009).

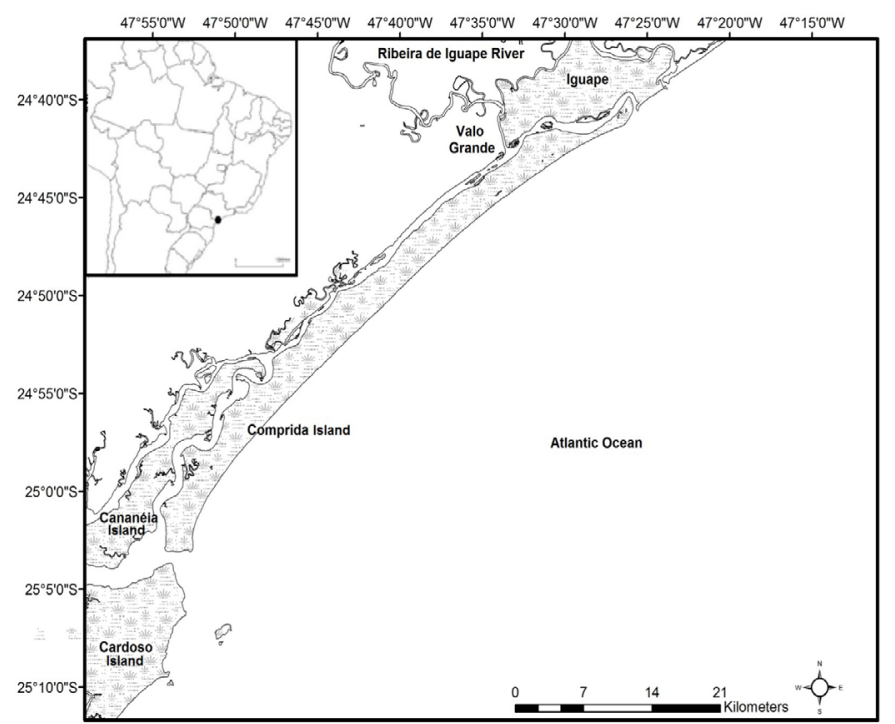

Figure 1. Map of the Complexo Estuarino Lagunar de Cananéia-Iguape, São Paulo State, southeast of Brazil. Adapted from Oliveira (2009).

\section{Data and samples collection}

Samples were obtained from stranded and dead animals on the beaches of the region between 2009 and 2012. The animals were submitted to biometry and macroscopic evaluation to assess the condition of the carcasses, identify sex and age classes, whenever possible. Tissue samples were collected only from fresh carcasses or when at an initial stage of decomposition (Geraci \& Lounsburry, 1993). Twenty seven animals, 11 males, 15 females and one not identified were analysed. The biometry corresponded to the curvilinear length of the animal, measured from the upper lip to the median notch of the caudal fin, following the corporal curvature. The age classes of the animals was arbitrarily estimated according to the curvilinear length. Animals of a length varying between 90 and $100 \mathrm{~cm}$ being classified as infants; animals between 111 and $165 \mathrm{~cm}$ as juveniles; and animals longer than $165 \mathrm{~cm}$ as adults, adapted to the species' propositions made by Rosas \& Monteiro-Filho (2002). During a necropsy, using a stainless steel scalpel, approximately $20 \mathrm{~g}$ of liver were removed, stored in plastic recipients and frozen at $-20^{\circ} \mathrm{C}$ until analyses.

Analytic procedures and cadmium determination Cadmium was evaluated due to its toxicity and ecological importance in the region. In the laboratory, the samples were homogenised by maceration and divided into sub-samples of approximately $5 \mathrm{~g}$ (wet weight). The method that was used was acid digestion. The digestion of the samples was performed with $30 \mathrm{ml}$ of aqueous solution of $\mathrm{HNO}_{3} 1: 1$, where they remained in reflux on a heating plate at $95^{\circ} \mathrm{C}$ for 12 hours until complete oxidation, evidenced by limpid extract. Next, the volume of the samples was reduced to $5 \mathrm{~mL}$. After cooling, the samples were filtered, transferred to volumetric balloons and had their volume gauged to $50 \mathrm{~mL}$ with distilled water. All the reagents utilized were of an analytic degree and the materials used during the procedures were previously decontaminated by washing with neutral detergent and bath in a solution of nitric acid (10\%) for $24 \mathrm{~h}$. 
Cadmium quantification was realized by Flame Atomic Absorption Spectrometry (FAAS) Shimadzu AA6800. The standard solution was prepared with successive dilutions using a stock solution of $\mathrm{Cd}$ $\left(1.000 \mathrm{mg} / \mathrm{L}^{-1}\right)$, using $13 \% \mathrm{v} / \mathrm{v} \mathrm{HNO}_{3}$. The calibration curve ranged from 0.01 to $1.0 \mathrm{mg} / \mathrm{L}$, with 0.9998 linearity. The Limit of Quantification (LOQ) of the method for the metal was $0.1 \mu \mathrm{g} \cdot \mathrm{g}^{-1}$. The quality of the results was accompanied with the use of an analytical blank and the determination performed in triplicate.

Due to the lack of certified reference material (CRM) of aquatic mammal tissues, the exactitude of the method was verified with CRM used to guarantee the internal standards in the laboratory. These were: RTC-CRM031-040 with an analytical result of $223.18 \mathrm{mg} / \mathrm{kg}$ (dry weight), which is in accordance with certified values $(212 \mathrm{mg} / \mathrm{kg})$ with a coefficient of variation (CV) of $1,78 \%$; and $\mathrm{EU}-\mathrm{H}-3$ with an analytic result of $0.225 \mathrm{mg} / \mathrm{L}$ according to the certificate $(0.228 \mathrm{mg} / \mathrm{L})$ with $0,999 \% \mathrm{CV}$.

\section{Data treatment}

The average values of the triplicate were considered, these results were used for data treatment. Statistical analyses were performed using
STATISTICA® 7.0. Data normality was tested with the Shapiro-Wilk's test. As data was not on normality $(w=0.60191 ; p=0.000)$, non-parametric tests were applied owing to the results. The Kruskal-Wallis test was performed to compare cadmium values among age classes. To compare concentrations between sexes in adults, the Mann-Whitney U-test was used. The Spearman non-parametric correlation was used to observe the correlation between the curvilinear length and the cadmium concentrations. For all cases, the considered significance level was 0.05 .

\section{RESULTS}

Due to limitation of the analytical method used, eleven of the animals did not exceeded the LOQ of $0.1 \mu \mathrm{g} \cdot \mathrm{g}^{-1}$. The concentrations of cadmium in the livers varied from above detection limit to $1.79 \mu \mathrm{g} \cdot \mathrm{g}^{-1}$ (wet weight), for a average concentration of $0.39 \mu \mathrm{g} \cdot \mathrm{g}^{-1}$, with a standard deviation of 0.47 . Data about collected animals and their respective cadmium concentration values are shown in Table 1.

Tabela 1: Data about S. guianensis sampled during the period of January 2009 and July 2012 in the Complexo Estuarino Lagunar de Cananéia-Iguape and values of cadmium concentrations in livers (in $\mu \mathrm{g} / \mathrm{g}-1$ wet weight).

\begin{tabular}{|c|c|c|c|c|c|c|}
\hline & \multirow[b]{2}{*}{ Sample ID } & \multicolumn{4}{|c|}{ Curvilinear } & \multirow[b]{2}{*}{$\mathrm{Cd}$} \\
\hline & & $\begin{array}{c}\text { Collection } \\
\text { date }\end{array}$ & Sex & $\begin{array}{l}\text { length } \\
\text { (cm) }\end{array}$ & Age Class & \\
\hline & Sg01 & $16 / 01 / 2009$ & $M$ & 176 & Adult & $1.06 \pm 0.03$ \\
\hline & $\mathrm{Sg} 02$ & $10 / 04 / 2009$ & $M$ & 195 & Adult & $<L O Q$ \\
\hline & $\mathrm{Sg03}$ & $20 / 05 / 2009$ & $M$ & 203 & Adult & $<L O Q$ \\
\hline & Sg04 & $18 / 06 / 2009$ & $\mathrm{~F}$ & 165 & Adult & $<L O Q$ \\
\hline & $\mathrm{Sg} 05$ & $21 / 07 / 2009$ & $M$ & 203 & Adult & $0.13 \pm 0.03$ \\
\hline & Sg06 & $13 / 08 / 2009$ & $\mathrm{~F}$ & 188 & Adult & $<L O Q$ \\
\hline & Sg07 & $23 / 08 / 2009$ & $M$ & 192 & Adult & $<L O Q$ \\
\hline & Sg08 & $30 / 08 / 2009$ & n.a. & n.a. & Infant & $0.21 \pm 0.007$ \\
\hline & Sg09 & $10 / 09 / 2009$ & $M$ & 208 & Adult & $1.79 \pm 0.04$ \\
\hline & Sg10 & $09 / 01 / 2010$ & $F$ & 169 & Adult & $1.01 \pm 0.008$ \\
\hline & Sg11 & $19 / 02 / 2010$ & $\mathrm{~F}$ & 149 & Juvenile & $0.16 \pm 0.007$ \\
\hline & Sg12 & $29 / 03 / 2010$ & $\mathrm{~F}$ & 198 & Adult & $0.20 \pm 0.04$ \\
\hline & Sg13 & $23 / 05 / 2010$ & $\mathrm{~F}$ & 204 & Adult & $0.15 \pm 0.02$ \\
\hline & Sg14 & 09/01/2011 & M & 155 & Juvenile & $0.21 \pm 0.01$ \\
\hline & Sg15 & $20 / 03 / 2011$ & $\mathrm{~F}$ & 198 & Adult & $0.29 \pm 0.001$ \\
\hline & Sg16 & $30 / 03 / 2011$ & M & 164 & Juvenile & $0.25 \pm 0.001$ \\
\hline & Sg17 & $15 / 04 / 2011$ & $\mathrm{~F}$ & 195 & Adult & $<L O Q$ \\
\hline & Sg18 & $11 / 05 / 2011$ & $\mathrm{~F}$ & 208 & Adult & $0.24 \pm 0.001$ \\
\hline & Sg19 & 08/08/2011 & $\mathrm{F}$ & 177 & Adult & $0.13 \pm 0.001$ \\
\hline & Sg20 & $26 / 08 / 2011$ & $\mathrm{~F}$ & 201 & Adult & $0.15 \pm 0.006$ \\
\hline & Sg21 & 02/09/2011 & $\mathrm{F}$ & 98 & Infant & $<L O Q$ \\
\hline ata expressed as mean $\pm S D(n=3)$ & Sg22 & $22 / 09 / 2011$ & $\mathrm{~F}$ & 208 & Adult & $0.14 \pm 0.006$ \\
\hline
\end{tabular}

n.a.- Data not available

$<$ LOQ - Values detected below the quantification limit of the method 
It was not possible to verify significant differences between age classes $(H=1.77 ; p=0.4121)$, this result is probably due to the discrepancy between the sampled number in the groups ( $\mathrm{n}$ adult $=22 ; \mathrm{n}$ juvenile=3; $n$ infant=2). (Figure 2).

Likewise, a significant statistical difference was also not verified between females $(n=13)$ and males

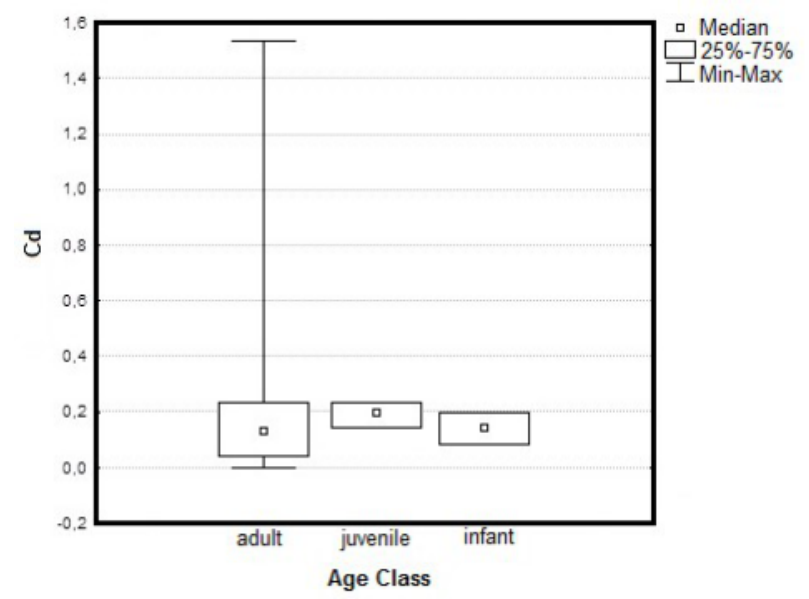

Figure 2. Median, quartiles, minimums and maximums of Cd concentrations in livers of Guiana dolphins (in $\mu \mathrm{g} . \mathrm{g}^{-1}$ wet weight) in relation to age classes (adult, juvenile and infant) $(p=0.4121)$.

\section{DISCUSSION}

In this study, the results reveal that the concentrations of cadmium in S. guianensis livers were in the same order of magnitude found in previous studies with the species on the Brazilian coast. Values lower than $0.1 \mu \mathrm{g} . \mathrm{g}^{-1}$ of cadmium in Guiana dolphin tissues have been previously reported by Lailson-Brito et al. (2000), Monteiro-Neto et al. (2003), Kunito et al. (2004), Dorneles et al. (2007a), Seixas et al. (2009) and Korn et al. (2010).

To determine the quantity of cadmium in biological samples can be problematic, especially due to the low concentrations of the metal and the large variety of matrixes among the samples (Davis et al., 2006), therefore, differences in metal concentrations between studies are common and expected, being important to take into consideration the techniques applied to the study. Even so, a comparison with literature becomes indispensable due to the limited bibliography that generally involves a low number of analysed individuals (Siciliano et al., 2005; Seixas et al., 2009).

Additionally, metals concentrations between studies can vary depending on various factors that affect the accumulation of metals in aquatic mammals (Seixas et al., 2009; Korn et al., 2010). The studied element and its availability in the environment, as well as the habit and feeding habits of the specie, play a fundamental role in this accumulation (André, 1997; Das et al., 2003). $(n=9)$ among adult animals $(U=55 ; z=1.20 ; p=0.22)$, with values considered as being statistically equivalents (Figure 3 ). The curvilinear length varied from 98 to $208 \mathrm{~cm}$ and it was seen that there was no significant correlation between cadmium concentrations in liver and the total curvilinear length of the sampled animals (Spearman $r=-0.04 ; p=0.83$ ).

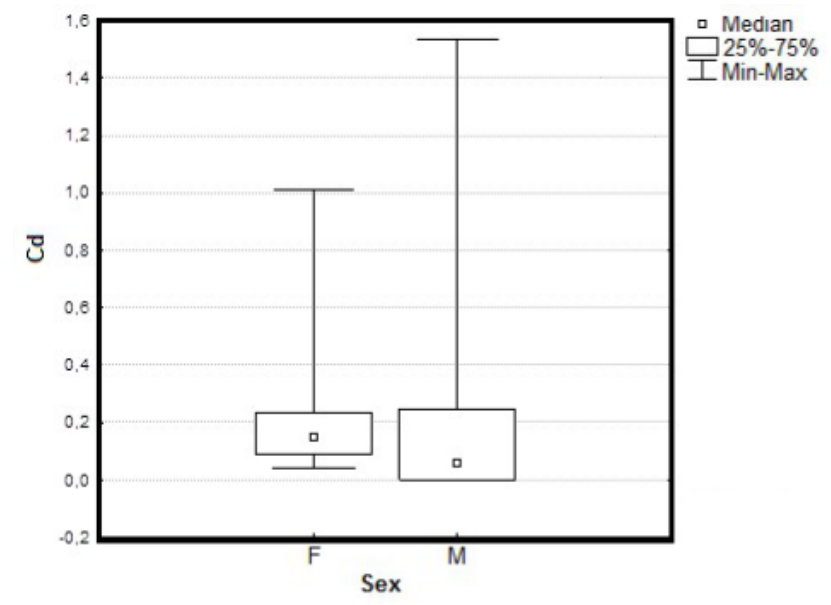

Figure 3. Median, quartiles, minimums and maximums of Cd concentrations in livers of Guiana dolphins (in $\mu \mathrm{g} . \mathrm{g}^{-1}$ wet weight) in relation to sexes (females and males) $(p=0.22)$.

Despite the cadmium absorption efficiency verified in the gastrointestinal tract on mammals be only of $5 \%$ (Elinder \& Järup, 1996), the principal means of cadmium contamination of aquatic mammals in the environment is through their feed (Das et al., 2003). The accumulation of the element by marine mammals is much more related to intake of cephalopods, which are known for their capacity of accumulating high contents of cadmium in their bodies, than an accumulation along the food chain (Lailson-Brito et al., 2000; Dorneles et al., 2007; Carvalho et al., 2008). Thus, species of cetacean that have squids as their predominant food item have higher concentrations of the metal when compared to species that feed especially on fish (Das et al., 2003; Seixas et al., 2009; Korn et al., 2010).

Guiana dolphins have most of their diet based on teleost fish (Oliveira et al., 2008), accumulating lower concentrations of the metal when compared to other species with a differentiated diet (Seixas et al., 2009; Korn et al., 2010). The feeding habits of the specie may also reflect their coastal and oceanic habits (Carvalho et al., 2008; Korn et al., 2010), as longer food chains, seen in oceanic environments, may favour the occurrence of higher cadmium levels on predators (Dietz et al., 1998).

For the region under study, species of fish of the Sciaenidae family were indicated as the most representative food items by Santos et al. (2002) and the predation of squid was also described. Lopes et al. (2012) observed that the ingestion of Lolliguncula 
brevis was more representative for animals in inner estuary and Doryteuthis plei was more representative for coastal animals, both of Loliginidae family. However, studies have shown that not all cephalopods may be considered important vectors of the transfer of the metal to cetaceans in the Brazilian coast, mainly to differences in cadmium bioaccumulation capacity between different squid species due to environmental and physiological aspects. Cephalopods of Loliginidae family, that live in coastal and continental shelf areas, exhibit lower cadmium concentrations in compare to others families that live in open oceans environment (Dorneles et al. 2007a; Dorneles et al., 2007b). This fact could indicate a low intake of cadmium to the Guiana dolphins in the studied area.

Nevertheless, environmental aspects must be taken in consideration when searching for explanation for the lower cadmium concentration in liver of Guiana dolphins. Regions close to the estuarine system houses several metallic mineral deposits, which were exploited mainly in the last century, causing local metal contamination, especially in the northern part of the system (Mahiques et al., 2009). However, high concentrations of the element were not reported in the sediment and waters of the system (Amorim et al., 2008; Souza, 2010), as to the local biota (Machado et al., 2002; Guimarães \& Sígolo, 2008), demonstrating low occurrence and viability of the metal in the environment.

Marine mammals generally do not present significant different patterns of accumulation of traceelements between the sexes (O'Shea, 1999). This pattern was also observed for S. guianensis on the Brazilian coast in previous studies by Monteiro-Neto et al. (2003), Kunito et al. (2004) and Seixas et al. (2009), as well as in this study, showing that, although males and females have some feeding differences in the study area (Oliveira et al., 2008), they don't represent differences in the accumulation of cadmium. Cadmium accumulation among age classes and the length of the animals did not show a significant difference, same as seen by Carvalho et al. (2008). However, researches held by Monteiro-Neto et al. (2003), Kunito et al. (2004) and Seixas et al. (2009) have shown higher contents of the metal in larger adult animals.

\section{CONCLUSION}

The results of this study had the same order of magnitude as those found in previous studies with the same species on the Brazilian coast. Since the complexity of the trophic chain is one of the major factors responsible for the accumulation of the element, the accumulation found in the livers of the Guiana dolphins may reflect its diet in the region and the bioavailability of the metal in the system. Furthermore, confirming those studies, no difference was observed in the content of $\mathrm{Cd}$ between sexes. Due to the discrepancy of data, the sampled quantity did not allow an encounter of significant relations between the accumulation of metal, the age classes and the curvilinear length. This study brings new data about the accumulation of $\mathrm{Cd}$ in $\mathrm{S}$. guianensis, contributing towards the status of conservation of these animals in Brazil.

\section{ACKNOWLEDGEMENTS}

We especially thank the Instituto de Pesquisas Cananéia (Cananéia Research Institute) and the Universidade Positivo (Positive University) for their logistic support in the field and laboratory analyses, respectively and Dr. Ana Tereza Bittencourt Guimarães for the statistical analyses. We also thank the PETROBRAS sponsorship through their Programa PETROBRAS Ambiental (PETROBRAS Environmental Programme), (Contrato $\left.n^{\circ} 6000.0063748 .10 .2\right)$.

\section{REFERÊNCIAS}

Amorim, E.P.; Fávaro, D.I.T.; Berbel, G.B.B. \& Braga, E.S. 2008. Assessment of metal and trace element concentrations in the Cananéia estuary, Brazil, by neutron activation and atomic absorption techniques. J. Radioanal. Nucl. Chem. Lett. 278(2):485-489.

André, J.M. 1997. Problematic and methodological approach to the estudy of the bioaccumulation of trace elements in delphinids. In: Jauniaux, T.; Bouquegneau, J. M. \& Coignoul, F. (eds) Marine mammals, seabirds and pollution of marine systems. University of Liege Press, Liege. 39-50pp.

Bonetti-Filho, J. \& Miranda, L.B. 1997. Estimativa de descarga de água doce no Sistema EstuarinoLagunar de Cananéia-Iguape. Rev. Bras. Oceanogr. 45(1/2): 89-94.

Bossart, G.D. 2006. Marine mammals as sentinel species for oceans and human health. Oceanography 19(2): 134-137.

Cardoso, L.M.N. \& Chasin, A.A.M. 2001. Ecotoxicologia do cádmio e seus compostos. CRA, Salvador, $122 p$.

Carvalho, C.E.V.; Di Beneditto, A.P.; Souza, C.M.M.; Ramos, R.M.A. \& Rezende, C.E. 2008. Heavy metal distribution in two cetacean species from Rio de Janeiro State, south-eastern Brazil. J. Mar. Biol. Assoc. UK 88: 1117-1120.

Da Silva, V.M. \& Best, R.C. 1996. Sotalia fluviatilis. Mamm. Species 527: 1-7. 
Das, K.; Debacker, V. \& Bouquegneau, J.M. 2000. Metallothioneins in marine mammals (a review). Cell. Mol. Biol. 46: 283-294.

Das, K.; Debacker, V.; Pillet, S. \& Bouquegneau, J.M. 2003. Heavy metals in marine mammals. In: Voss, J.G.; Bossart, G.D.; Fournier, M. \& O'Shea, T.J. (eds) Toxicology of Marine Mammals. Taylor \& Francis, New York. 135-167pp.

Davis, A.C.; Wu, P.; Zhang, X.; Hou, X. \& Jones, B.T. 2006. Determination of cadmium in biological samples. Appl. Spectrosc. Rev. 41: 35-75.

Dietz, R.; Pacyna, J.; Thomas, J. D. Heavy metals. AMAP Assessment Report-Arctic Pollution Issues. Oslo: Arctic Monitoring Assessment Programme, 1998. p. 373-524.

Dorneles, P.R.; Lailson-Brito, J.; Santos, R.A.; Costa, P.A.S; Malm, O.; Azevedo, A.F. \& Machado, J.P.T. 2007a. Cephalopods and cetaceans as indicators of offshore bioavailability of cadmium off Central South Brazil Bight. Environ. Pollut. 148: 352-359.

Dorneles, P.R.; Lailson-Brito, J.; Secchi, E.D.; Bassoi, M.; Lozinsky, C.P.C.; Torres, J.P.M. \& Malm, O. 2007b. Cadmium concentrations in franciscana dolphin (Pontoporia blainvillei) from south brazilian coast. Braz. J. Oceanogr. 55(3): 179-186.

Elinder, C.G.; Järup, L. 1996. Cadmium exposure and health risks: recente findings. Ambio. 25(5): 370-373.

Filla, G.F.; Atem, A.C.G.; Bisi, T.L.; De Oliveira, L.V.; Domit, C.; Gonçalves, M.; Havukainen, L.; Oliveira, F.; Rodrigues, R.G.; Rosas, F.C.W.; Santos-Lopes, A.R. \& Monteiro-Filho, E.L.A. 2008. Proposal for creation of a "zoning with regulation of use in the Cananéia estuarine-lagoon complex" aiming the conservation of the estuarine dolphin, Sotalia guianensis (van Bénéden) (Cetacea, Delphinidae). PanamJAS 3(1): 75-83.

Flores, P.A.C. \& Da Silva, V.M.F. 2009. Tucuxi and Guiana Dolphin (Sotalia fluvitilis and S. guianensis). In: Perrin, W.F.; Wursig, B. \& Thewissen, J.G.M. (eds) Encyclopedia of Marine Mammals, 2nd edn. Elsevier, Amsterdam. 1188-1192pp.

Geraci, J.R. \& Lounsburry, V. 1993. Marine Mammals Ashore: A Field Guide for Strandings. A\&M Sea Grant Publication, Texas, 371p.

Guimarães, V. \& Sígolo, J.B. 2008. Detecção de contaminantes em espécie bioindicadora (Corbicula fluminea) - Rio Ribeira de Iguape - SP. Quím. Nova 31(7): 1696-1698.

Havukainen, L.; Monteiro-Filho, E.L.A. \& Filla, G.F. 2011. Population density of Sotalia guianensis (Cetacea: Delphinidae) in the Cananéia region, Southeastern Brazil. Rev. Biol. Trop. 59(3): 1275-1284.
IUCN 2014. The IUCN Red List of Threatened Species. Version 2014.3. Available <www.iucnredlist.org>. Downloaded on 17 November 2014.

Kägi, J.H.R. 1991. Overview of metalothionein. In: Riordan, J.F. \& Val Lee, B.L. (eds) Methods in Enzymology, vol 205. Academy Press Inc. 613-626pp.

Korn, M.G.A.; Oliveira, P.V.; Rosa, S.M.; Santos, G.L. \& Teixeira, L.S.G. 2010. Determination of cadmium and lead in Cetacean Delphinidae tissue from the coast of Bahia state in Brazil by GFAAS. Microchem. J. 96: 12-16.

Kunito, T.; Nakamura, S.; Ikemoto, T.; Anan, Y.; Kubota, R.; Tanabe, S.; Rosas, F.C.; Fillmann, G. \& Readman, J.W. 2004. Concentration and subcellular distribution of trace elements in liver of small cetaceans incidentally caught along the Brazilian coast. Mar. Pollut. Bull. 51(8-12): 896-911.

Lailson-Brito, J.; Azeredo, M.A.A.; Saldanha, M.F.C.; Fernandez, M.A. \& Herms, F. 2000. Estudo ecotoxicológico das concentrações de cádmio em tecidos de golfinhos (Cetacea, Delphinidae) de hábitos costeiros e oceânicos, de águas do Estado do Rio de Janeiro. In: Espíndola, E.L.G.; Paschoal, C.M.R.B.; Rocha, O. Bohrer, M.B.C. \& Neto, A.L.O. (eds) Ecotoxicologia: Perspectivas para o século XXI. RIMA, São Carlos. 183-197pp.

Lopes, X.M.; Silva, E.; Bassoi, M.; Santos, R.A.; Santos, M.C.O. 2012. Feeding habits of Guiana dolphins, Sotalia guianensis, from south-eastern Brazil: new items and a knowledge review. J. Mar. Biol. Ass. U. K. 92(8): 1723-1733.

Machado, I.C.; Maio, F.D.; Kira, C.S. \& Carvalho, M.F.H. 2002. Estudo da Ocorrência dos metais pesados $\mathrm{Pb}, \mathrm{Cd}, \mathrm{Hg}$, Cu e $\mathrm{Zn}$ na ostra de mangue Crassostrea brasiliana do estuário de Cananéia - SP, Brasil. Rev. Inst. Adolfo Lutz 61(1): 13-18.

Mahiques, M.M.; Burone, L.; Figueira, R.C.L.; LavenéreWanderley, A.A.O.; Capellari, B.; Rogacheski, C.E.; Barroso, C.P.; Santos, L.A.S.; Cordero, L.M. \& Cussioli, M.C. 2009. Anthropogenic influences in a lagoonal environment: a multiproxy approach at the Valo Grande mouth, Cananeia-Iguape system (SP Brazil). Braz. J. Oceanogr. 57: 325-37.

Monteiro-Filho, E.L.A.; Filla, G.F.; Domit, C. \& De Oliveira, L.V. 2006. Cetacea. In: Reis, N.R.; Peracchi, A.L.; Pedro, W.A. \& Lima, I.P. (eds) Mamíferos do Brasil, 1st edn. Universidade Estadual de Londrina, Londrina. 305-341pp.

Monteiro-Neto, C.; Itavo, R.V. \& Moraes, L.E.S. 2003. Concentrations of heavy metals in Sotalia fluviatilis (Cetacea:Delphinidae) off the coast of Ceará, northeast Brazil. Environ. Pollut. 123: 319-324.

Oliveira, M.R.; Rosas, F.C.W.; Pinheiro, P.C. \& Santos, R.A.S. 2008. Alimentação. In: Monteiro- 
Filho, E.L.A. \& Monteiro, K.D.K.A. (eds) Biologia, Ecologia e Conservação do Boto-Cinza, 1st edn. Páginas \& Letras, São Paulo. 91-101pp.

Oliveira, T.C.G. 2009. Diversidade de espécies e comportamento de uma comunidade de aves estuarinas em um baixio no Lagamar de Cananéia, litoral sul do estado de São Paulo, Brasil. Dissertation, Universidade Federal do Paraná. $132 p$.

O'Shea, T.J. 1999. Environmental contaminants and marine mammals. In: Reynolds III, J.E. \& Rommel, A.S. (eds) Biology of Marine Mammals. Smithsonian Inst Press, Washington and London, 485-563pp.

Santos, M.C.O.; Acuña, L. \& Rosso, S. 2001. Insights on site fidelity and calving intervals of the marine tucuxi dolphin (Sotalia fluviatilis) in south-eastern Brazil. J. Mar. Biol. Assoc. UK 81(6): 1049-1052.

Santos, M.C.O. \& Rosso, S. 2008. Social organization of marine tucuxi dolphins, Sotalia guianensis, in the Cananéia estuary of southeastern Brazil. J. Mammal 88(2): 347-355.

Santos, M.C.O.; Rosso, S.; Santos, R.A.; Lucato, S.B. \& Bassoi, M. 2002. Insights on small cetacean feeding habits in southeastern Brazil. Aquatic. Mammals 28(1): 38-45.

Schaeffer-Novelli, Y.; Mesquita, H.S.L. \& CintrónMolero, G. 1990. The Cananéia lagoon estuarine system, São Paulo, Brazil. Estuaries 13(2): 193-203.

Siciliano, S.; Alves, V.C. \& Hacon, S. 2005. Aves e mamíferos marinhos como sentinelas ecológicas da saúde ambiental: Uma revisão do conhecimento brasileiro. Cad. Saúde Colet. 13(4): 927-946.

Rosas, F.C.W. \& Monteiro-Filho, E.L.A. 2002. Reproduction of the Estuarine Dolphin (Sotalia guianensis) on the Coast of Paraná, Southern Brazil. J. Mammal. 83(2): 507-515.

Seixas, T.G.; Kehrig, H.A.; Di Beneditto, A.P.M.; Souza, C.M.M.; Malm, O. \& Moreira, I. 2009. Trace elements in different species of cetacean from Rio de Janeiro Coast. J. Braz. Chem. Soc. 20: 243-251.

Souza, A.P.R. 2010. Determinação dos íons de cádmio e zinco no Sistema Estuarino-Lagunar de Cananéia-Iguape por voltametria de redissolução anódica. Dissertation, Universidade de São Paulo. $105 p$.

Tessler, M.G. \& Souza, L.A.P. 1998. Dinâmica sedimentar e feições sedimentares identificadas na superfície de fundo do Sistema CananéiaIguape, SP. Rev. Bras. Oceanogr. 46(1): 69-83. 